\title{
The Role of Nurturing Technopreneurship Education and Building University Students' Entrepreneurial Mindsets and Skill Sets in Fostering Digital Innovation and Augmenting the Tech Start-Up Ecosystem in Bahrain
}

\author{
Sama'a Al Hashimi \\ University of Bahrain, Sakheer, Kingdom of Bahrain \\ https:// orcid.org/0000-0003-4355-8699 \\ Yasmina Zaki, Ameena Al Muwali and Nasser Mahdi \\ University of Bahrain, Sakheer, Kingdom of Bahrain \\ https:// orcid.org/0000-0002-2100-2895 \\ https://orcid.org/0000-0003-2261-9827 \\ https://orcid.org/0000-0002-0763-2911
}

\begin{abstract}
This paper examines the relationship between the success of tech start-ups and the educational backgrounds of their owners. To better comprehend and encourage technopreneurial growth, it is essential to understand the educational background of tech start-up founders in Bahrain. The paper attempts to explore whether or not different educational qualifications of tech start-up founders are associated with their success. It also aims to investigate the pedagogical approaches, strategies, skills, and objectives that may have contributed to the success of leading technopreneurs, locally and globally in an effort to suggest the right practices to implement in Bahrain in order to emulate their educational experiences. The research qualitatively investigates the perceptions and academic experiences of the founders of five innovative Bahraini digital applications in an attempt to explore the role of their education in their success and growth. In addition, twelve support organizations in Bahrain were interviewed to examine the influence of higher education on entrepreneurial success. The paper argues that education is very essential to entrepreneurial success, and its findings provide clear evidence of the impact of education which focuses on fostering creative thinking, innovation, and team-working skills on technopreneurial success. These findings may have implications for universities in Bahrain to promote successful entrepreneurs through integrating the best practices in innovation and entrepreneurship education into the curriculum, and strengthening their cooperation with the government and various support organizations. Finally, the paper provides higher education institutions with guidelines and recommendations to maximize their role in the tech start-up ecosystem in Bahrain.
\end{abstract}

Keywords: education; start-ups; technopreneur; entrepreneurship; accelerators; digital applications 


\section{Introduction}

The growing impact of successful tech start-ups in developing the start-up ecosystem in Bahrain calls for an investigation into the role of the educational background and academic qualifications of their founders in leading to their success. Tripathi et al. (2019) define a start-up ecosystem as "the phenomenon in which startups and their supporting elements interact in an environment that is built to foster these startups' development and growth" (p.1)

The Kingdom of Bahrain and many other countries around the globe have become viable start-up ecosystems (The Global Startup Ecosystem Report (GSER), 2020). The Covid-19 pandemic has led to a major transition and to a growing dominance of tech start-up ecosystems globally (GSER2020). These ecosystems can create more jobs, enhance innovation, and support economic growth. In order for these ecosystems to grow, they must be supported through a "regulatory environment, access to resources, true multi-stakeholder involvement, public-private collaboration, and mentorship networks that nourish innovators" (GSER2020, p.8). The start-up ecosystem has a direct effect on boosting global and local economic development. It fosters innovation and raises competitiveness in the local community. Moreover, it creates jobs and makes money for investors and stakeholders, which ultimately leads to economic growth (Szarek \& Piecuch, 2018). In order for a digital start-up ecosystem to flourish, support organizations and policy-makers should extend their consideration of entrepreneurial activities and endeavours in educational institutions (Ratzinger et al., 2018).

This paper examines the relationship between the success of tech start-ups and the educational backgrounds of their founders. Some researchers argued that there is a relationship between the success of tech start-ups and the educational backgrounds of their owners (Oliveira, 2019 \& Kurczewska \& Mackiewicz, 2020). This paper attempts to examine this relationship. As few studies appear to exist in the area of technopreneurship education and its possible role in fostering digital innovation in the start-up ecosystem in Bahrain, we conducted semi-structured in-depth interviews and a short survey with technopreneurs who founded innovative digital applications in Bahrain, in an attempt to explore the role of their educational background in their success and growth. In addition, representatives from twelve support organizations in Bahrain were interviewed to better understand the influence of higher education on entrepreneurial success. The paper also aims to investigate the pedagogical approaches, strategies, and skills that may have contributed to the success of leading technopreneurs, locally and globally to suggest the most effective practices to implement in higher education institutions in Bahrain in order to emulate their educational experiences.

In order to fulfil the above-mentioned purpose of this paper, the following research questions and objectives were formulated;

\subsection{Research Questions}

This research attempts to find answers to the following questions;

(1) Is there a relationship between the success of tech start-ups and the educational backgrounds of their owners? 
(2) What are the best practices and most effective pedagogical approaches in innovation and entrepreneurship education that can be implemented by universities in Bahrain to create well-skilled technopreneurs who can reinvigorate Bahraini business?

\subsection{Research Objectives}

(1) To investigate the relationship between the success of tech start-ups and the educational backgrounds of their owners

(2) To explore and benchmark the best practices and most effective pedagogical approaches that can be implemented by universities in Bahrain to create successful technopreneurs

(3) To foster entrepreneurial attitudes and skills among students in Bahrain

(4) To identify the most important technopreneurship skills that universities in Bahrain need to transfer to students and the most effective approaches to implement in order to equip students with the most important skills, knowledge, attitudes, and mindsets required to start and maintain a successful venture

(5) To promote and encourage the development of personal qualities and skills that are relevant to technopreneurship

In the first section, the paper presents a general overview of the research problem, significance, objectives, and methodology. The second section explores exceptional worldwide practices in entrepreneurship education, and reviews previous research and relevant literature related to the relationship between the educational background and entrepreneurial success. It contains content analysis of relevant literature. The third section discusses and analyses the respondents' answers and presents the findings and their implications in an attempt to inform and provide higher education institutions in Bahrain with guidelines and recommendations to maximize their role in preparing students with suitable skill sets for the tech start-up ecosystem in Bahrain. The eventual aim is for these findings to provide valuable insights to universities and training institutions in Bahrain to promote successful entrepreneurs through integrating the best practices in innovation and entrepreneurship education into the curriculum, and strengthening their cooperation with the government and various support organizations.

The following section provides a literature review that explores the relationship between the educational background and entrepreneurial success and sets the foundation for the most effective entrepreneurship pedagogical practices, locally and globally.

\section{Literature Review; The Relationship between Educational Background and Entrepreneurial Success}

Entrepreneurship is a key factor for economic growth. It became crucial for educational institutions to support entrepreneurship more than any other time before. Promoting leading entrepreneurial education in schools and universities can have a positive impact on business dynamics and economic growth. For this reason, many highly ranked universities started to adopt this field in their 
pedagogical curricula in an attempt to equip their students with the theoretical and practical skills they need to establish their start-ups.

In 2014, a guide for entrepreneurship educators by the European Commission reported that "students who participated in entrepreneurial programs are three to six times more likely to start a business than those who do not receive entrepreneurship education." (Entrepreneurship 2020 Unit, 2014, p. 4). Thus, it has become imperative to invest in entrepreneurship education. This literature review sheds light on some successful models and practices that have been implemented in high-ranked universities. It attempts to explore the most effective approaches to give students awareness, knowledge, skills, and all essential requirements to have an entrepreneurial mindset and become successful entrepreneurs. McGuigan (as cited in Toit \& Gaotlhobogwe, 2018) defines entrepreneurship education as "as knowledge, skills and attitudes which contribute to entrepreneurial thinking and actions that learners can apply in their everyday lives, their future careers, their communities and/or their own new ventures"(p.39).

There are various views in previous literature on how entrepreneurship education should be structured, and which methods are most effective. Ji and Zhao (2014) identified the main elements of entrepreneurship education in educational institutions. According to them, these elements are: students, teachers, carrier and environment. Sanchez et al. (2017) reported that key competencies in entrepreneurship include autonomy, teamwork, adaptability, management of resources, social networks, risk taking, individual and social responsibility, interaction, and social skills.

Entrepreneurship education can be implemented using various methods, theories, models and measures. Capiene and Ragauskaite (2017) recommended the establishment of a center for entrepreneurship development in universities and suggested a model of entrepreneurship education, which includes three stages. The model includes traditional methods in the first stage such as seminars, trainings, lectures, events, etc., while other stages are oriented towards actions and practical tasks "to stimulate behavioral changes and development of psychological characteristics necessary for entrepreneurship" (Čapienè \& Ragauskaitè, 2017, p. 2). The second stage includes tools for simulating the development of a new business, for instance, business plans, creating and thinking together with mentors and consultants. This allows students to go successfully to the third stage where "students have to be encouraged to participate in national and international contests for developing ideas, broaden their professional horizons and create partnership of business projects" (Čapienè \& Ragauskaitè, 2017, p. 2).

The review of literature shows that several studies attempted to represent evidence of the increasing importance of education to entrepreneurs, and suggested that entrepreneurs with a good general education tend to be more successful than those with less adequate education (Oliveira, 2019; Kurczewska \& Mackiewicz, 2020). 
Nebessayeva et al. (2018) do not believe that a business degree is vital to successfully start and operate a start-up as long as university students, regardless of their degrees learn concepts such as design thinking, risk-taking, and rulebreaking. They stated that although entrepreneurship is usually taught in business programs, there is evidence to suggest that there is a correlation between liberal arts education and becoming a successful entrepreneur, and that some entrepreneurs have benefitted from a liberal arts education. They believe that this correlation is not surprising because liberal arts equip students with critical, creative and lateral thinking skills that are pertinent to entrepreneurship. According to them any pedagogy, such as art and design, that encourages risktaking and innovation attitudes will support the development of an entrepreneurial mindset (Nebessayeva et al., 2018).

Kurczewska, A., \& Mackiewicz, M. (2020) seem to agree with Nebessayeva et al. (2018) in that having a business degree or managerial experience is not necessarily a prerequisite for becoming a successful technopreneur. They, therefore, recommend cross-disciplinary entrepreneurship education because collaboration across disciplines may lead to more successful outcomes, as their research findings revealed that "individuals with more diverse educational and professional backgrounds tend to have both greater chances of starting a company, as well as a higher probability of entrepreneurial success" (Kurczewska \& Mackiewicz 2020, p.1) Similarly, Sorgner \& Fritsch (2018) believe that a wideranging set of cross-disciplinary skills and knowledge let students become entrepreneurs, in contrast to having more specialized skills and knowledge.

Unlike the aforementioned researchers who do not believe that having a business degree or managerial experience is a prerequisite for entrepreneurial success, the results of a study conducted by Staniewski (2016, p.1) indicated that "entrepreneurs with managerial experience, an effective entrepreneur in the family, unique knowledge, and whose employees have unique knowledge obtain higher mean scores in the general indicator of entrepreneurial success".

Boldureanu et al. (2020) stressed that university programs that aim to enhance entrepreneurial skills should be designed differently for business and nonbusiness students because learning successful entrepreneurial stories influences business and non-business students differently.

Many universities around the world realized that embedding entrepreneurship education in their curricula, programs, courses, or activities can lead to the creation of an innovative entrepreneurial culture and a successful start-up ecosystem. The universities in China, for instance, started offering entrepreneurship programs, competitions, and sandbox simulations in order to improve the success rates of their students in becoming entrepreneurs (Liu et al., 2019).

Lynch et al. (2019) argued that in order for entrepreneurship education to be effective it must enable students to develop skills in imagination, flexibility, design thinking and creativity as well as developing enough skills to think 
conceptually and to perceive change as opportunity. In order to achieve these standards, they suggested that university programs must not emphasize theory at the expense of practical approaches, but should rather teach students how to practically apply design thinking "in real-life beyond the context of the course." (Lynch et al., 2019, p.1).

The World Economic Forum has set up guidelines for entrepreneurial education. These include the employment of approaches that are based on interactive learning with the use of digital and multimedia tools, experiential learning and learning by doing which involve trial and error, multidisciplinary programs and projects, games and simulations (OECD, 2016), case studies, and internships that involve start-ups and interaction with mentors and entrepreneurs (World Economic Forum, 2016). On the other hand, some researchers (Sousa, 2018, p.6) recommended that universities focus on enhancing the following skills: "capacity to be innovative and creative; capacity to diversify the business area; capability to identify and exploit new business opportunities; project management skills to link project goals within the business context; ability and willingness to undertake risk; ability to organize the necessary resources to respond to the opportunity; capability to create and develop national and international networks". Additional important skills include self-confidence, drive for achievement, risk-taking, leadership, originality, creativity, flexibility, and the capacity to be future-oriented (Kimball \& Lussier, 2020).

All the aforementioned studies prove the importance of the educational background on the success of entrepreneurs. They stress the influence of education on the success of start-ups and their founders. This reflects the ongoing need for educational institutions to keep up with technological developments, business competition, and the growing global economy. This need has been realized by authorities, support organizations, and entrepreneurs in the Kingdom of Bahrain.

The Kingdom of Bahrain is considered as one of the leading economies in the GCC region, and was ranked as the 72nd most innovative economy in the Global Innovation Index 2018 (Dutta et al., 2018). It was also ranked 35th for entrepreneurial attitude, activity and aspiration in the Global Entrepreneurship Index 2018 (Acs et al., 2018). A recent survey by Ernst \& Young (2018) found that $70 \%$ of young Bahrainis were interested in starting their own businesses (Aboukhsaiwan, 2017). The number of tech start-ups in Bahrain has already grown significantly in recent years and strong growth is expected in the near future. According to a publication that was initiated by the Bahrain Chamber of Commerce and Industry (BCCI), and produced in cooperation with Oxford Business Group (2020, p.8),

"Bahrain is home to some of the region's most computer-savoy citizens, as well as some of the Middle East's most forward-looking legislation in terms of fostering the development of the tech economy, with pro-visions ranging from subsidization to government-funded training." (Oxford Business Group, 2020, p.8). 
The National Higher Education Strategy (2014-2024) report of the Kingdom of Bahrain stated that entrepreneurship education currently is still at its basic level, and that it is offered in an uncoordinated manner and lacks strong support and integration across academic levels and curriculum (Kingdom of Bahrain Ministry of Education [KBME], 2014). The Minister of Education, Dr. Majid bin Ali AlNuaimi noted in the National Higher Education Strategy Report (2014-2024) for the Kingdom of Bahrain that "the sector must perform a critical role in terms of addressing the skill needs of the workforce of tomorrow and developing our knowledge economy through improving overall quality, skills, entrepreneurship and technology" (KBME, 2014, p.11), and he reported that "Higher education in Bahrain has a central role to play in economic growth, investment and innovation. This important sector requires a strategic vision in order to face the challenges of the future" (KBME, 2014, p.11). In the academic year 2007/2008, the Ministry of Education introduced entrepreneurship education in the study plan of two tracks: The industrial and the commercial (KBME, 2014). Figure 1 summarizes the national higher education strategy and the planned practices and approaches for this integration.

There are number of initiatives that support entrepreneurship education programs, which are offered by regional and international institutions in Bahrain. These include Tamkeen, INJAZ of Bahrain, Rowad Training, and The UN Industrial Development Organization UNIDO/Office of investment and technology promotion. Bahrain is working on integrating entrepreneurship in higher education; it recognized the significance of entrepreneurship in its economic growth and urged universities to implement entrepreneurship education and hone students' entrepreneurial competencies (Lagaras, 2017). Since 2004, for instance, the Center for International Private Enterprise (CIPE) has partnered with Tamkeen and the William Davidson Institute (WDI) at the University of Michigan to implement an Entrepreneur Mentoring program, in which 48 Bahraini instructors received training on strategies for teaching entrepreneurship skills to more than 270 university students (Center for International Private Enterprise (CIPE), 2021). 


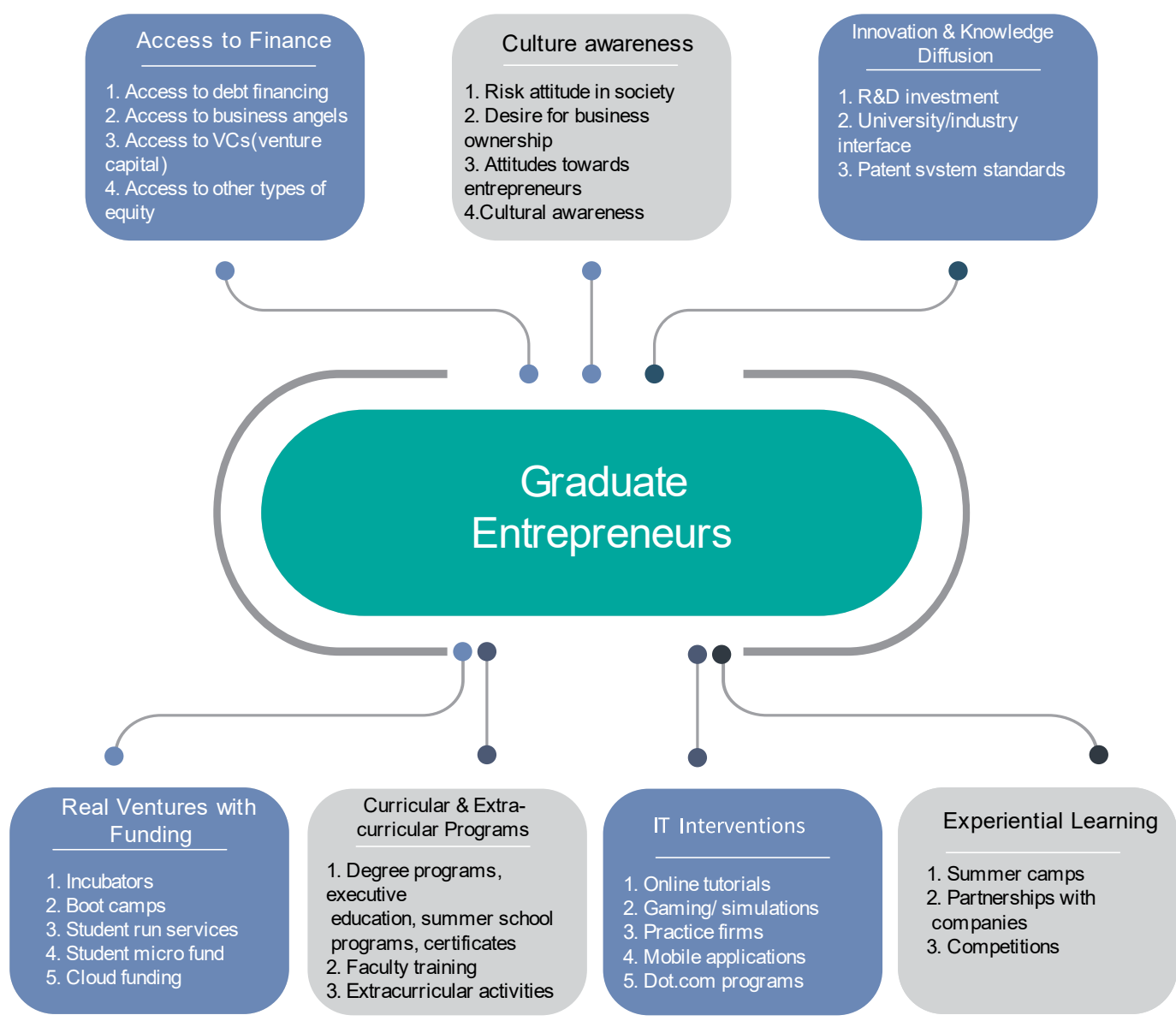

Figure 1. The national higher education strategy for integrating entrepreneurship in higher education in Bahrain (Reproduced by the authors of this research from

(KBME, 2014, p. 32)

The National Higher Education Strategy 2014-2024 Report (KBME, 2014) suggested indicators to measure the impact of Entrepreneurship Education in Bahrain such as the number of universities offering entrepreneurship training programs, the number of students going through entrepreneurship training programs, the percentage of students starting their business during university, the percentage of students starting their business post-university, and the number of technology incubators / start-ups by graduates in Bahrain.

Recently entrepreneurship in Bahrain, and especially the development of tech start-ups, has witnessed significant growth. The heightened awareness and interest in entrepreneurship shifted the academic focus towards the creation of a number of academic courses, programs and curricula in entrepreneurship.

The following section seeks to understand the skill sets and educational background of technopreneurs in Bahrain in an attempt to provide insights into what academic factors influence the success or failure of their tech start-ups. 


\section{Research Methodology}

The research qualitatively investigates five tech start-ups by innovative Bahraini technopreneurs in an attempt to explore the role of their educational background in their success. In addition, representatives from twelve support organizations in Bahrain were interviewed to better comprehend the influence of education on entrepreneurial success. The qualitative research method is used because "it allows entrepreneurship researchers to inductively or abductively build theories, in close interaction with contexts, meanings, and processes" (Van Burg et al., 2020, p. 4). Van Burg et al. (2020) believe that qualitative research is appropriate for studying hard-to-measure entrepreneurship phenomena that require building better understanding of how the lived experiences of entrepreneurs may affect entrepreneurial outcomes.

\section{Data Collection Instruments}

The interviews that were conducted with the twelve representatives were semistructured and involved the following themes: services provided to support techpreneurs; stages of providing support; criteria for accepting to support techpreneurs; strategies employed to attract creative techpreneurs; views on the success of tech start-ups and the educational backgrounds of their owners; views on techpreneurs' most required skill set and prominent skills for shaping successful techpreneurs.

The interviews that were conducted with the founders of the five tech start-ups were also semi-structured and involved questions about their academic backgrounds and the most effective educational experiences, skills, and strategies that contributed to equipping them with the most important skills, knowledge, attitudes, and mindsets required to start and maintain a successful venture. Through a short survey, they were also asked about the factors that led to the success of their start-ups, the obstacles and challenges they encountered, their financial and marketing plans, and their recommendations and insights on the most important personal qualities and skills. The interviews mainly revolved around their suggestions and perceptions of the most effective pedagogical approaches that can be fostered and implemented by universities in Bahrain to create successful technopreneurs.

The interviews lasted on average 60 minutes. Each interview was digitally recorded, and a verbatim transcript was prepared by the researchers.

\section{Sample Size and Participants}

Six representatives were males, and six were females. The five tech-startups had eight founders/co-founders who were interviewed as part of this research. Two out of the eight founders were females, and six were males. Their ages ranged between 27 to 47 years at the time of the study and their years of experience as entrepreneurs ranged between 4 and 27 years. All participants provided informed consent to participate in the research, and the start-up founders provided written consent to reveal their names and the details that are listed in Table 1 about their start-ups. In addition, in order to ensure the validity of the data collected and to comply with research ethics, all the participants were invited to review the 
transcripts and make necessary corrections. The edits made by them to their transcripts were immediately documented.

\section{Results \& Discussion}

Support Organization's Outlooks on the Relationship between the Educational Background and Entrepreneurial Success

The previous section demonstrated that numerous studies support the notion that entrepreneurs' success is related to their educational background in addition to other factors (e.g., Kurczewska \& Mackiewicz, 2020; Oliveira et al., 2019). This section reviews the different opinions of eight Bahraini technopreneurs, who were purposively selected due to the success of their tech start-ups in Bahrain, and another sample of twelve support organizations' representatives, who were purposively selected based on their prominence in the entrepreneurship scene in Bahrain. The technopreneurs were the founders of the tech start-ups listed in Table 1. The researchers targeted the support organizations' and tech start-ups' executive managers or their representatives to know their points of view towards the relationship between technopreneurial success and the educational background of technopreneurs. In-depth semi-structured interviews and a questionnaire were conducted with them in an attempt to investigate whether or not different educational majors, educational levels, or even particular educational experiences of technopreneurs are associated with the success of their start-ups.

Table 1. A List of the tech start-up founders who were interviewed in this research

\begin{tabular}{|c|c|c|c|c|c|c|}
\hline $\begin{array}{l}\text { Name of } \\
\text { Founders }\end{array}$ & $\begin{array}{l}\text { Academic } \\
\text { Qualification }\end{array}$ & $\begin{array}{l}\text { Name } \\
\text { of Start- } \\
\text { up }\end{array}$ & $\begin{array}{l}\text { Description } \\
\text { of Start-up }\end{array}$ & $\begin{array}{l}\text { Domain/ } \\
\text { Services }\end{array}$ & $\begin{array}{l}\text { Date } \\
\text { Founded }\end{array}$ & Stage \\
\hline $\begin{array}{l}\text { Abdulla Al- } \\
\text { Aradi }\end{array}$ & $\begin{array}{l}\text { Bachelor of } \\
\text { Engineering in } \\
\text { Petroleum and } \\
\text { natural gas } \\
\text { engineering/ } \\
\text { Sultan Qaboos } \\
\text { University }\end{array}$ & Akalati & $\begin{array}{l}\text { Akalati is an } \\
\text { app } \\
\text { specialized in } \\
\text { catering } \\
\text { services for } \\
\text { events, } \\
\text { occasion and } \\
\text { gatherings }\end{array}$ & $\begin{array}{l}\text { Food and } \\
\text { Catering }\end{array}$ & $\begin{array}{l}\text { February } \\
2018\end{array}$ & $\begin{array}{l}\text { Pre- } \\
\text { Seed }\end{array}$ \\
\hline $\begin{array}{l}\text { Zaman AH. } \\
\text { Zaman }\end{array}$ & $\begin{array}{l}\text { Bachelor of } \\
\text { Business } \\
\text { Administration/ } \\
\text { American } \\
\text { University in Dubai } \\
\text { BA Management } \\
\text { Information } \\
\text { Systems/American } \\
\text { University of } \\
\text { Sharjah }\end{array}$ & Skiplino & $\begin{array}{l}\text { Skiplino is a } \\
\text { cloud-based } \\
\text { queue } \\
\text { management } \\
\text { system that } \\
\text { can monitor } \\
\text { the data in real } \\
\text { time, and get } \\
\text { the customer } \\
\text { feedback. }\end{array}$ & $\begin{array}{l}\text { Queue } \\
\text { management } \\
\text { system }\end{array}$ & $\begin{array}{l}\text { August } \\
2015\end{array}$ & Series A \\
\hline $\begin{array}{l}\text { Yasser } \\
\text { Abdel Aziz }\end{array}$ & $\begin{array}{l}\text { Bachelor of Science } \\
\text { (BSc) in Accounting } \\
\text { and Finance/ } \\
\text { Bangor University }\end{array}$ & Malaeb & $\begin{array}{l}\text { Malaeb is an } \\
\text { application } \\
\text { That allows } \\
\text { users to book }\end{array}$ & $\begin{array}{l}\text { Booking } \\
\text { stadiums }\end{array}$ & May 2016 & Seed \\
\hline
\end{tabular}




\begin{tabular}{|c|c|c|c|c|c|c|}
\hline $\begin{array}{l}\text { Name of } \\
\text { Founders }\end{array}$ & $\begin{array}{l}\text { Academic } \\
\text { Qualification }\end{array}$ & $\begin{array}{l}\text { Name } \\
\text { of Start- } \\
\text { up }\end{array}$ & $\begin{array}{l}\text { Description } \\
\text { of Start-up }\end{array}$ & $\begin{array}{l}\text { Domain/ } \\
\text { Services }\end{array}$ & $\begin{array}{l}\text { Date } \\
\text { Founded }\end{array}$ & Stage \\
\hline & $\begin{array}{l}\text { Diploma in } \\
\text { Accounting and } \\
\text { Finance - Bahrain } \\
\text { Institute for } \\
\text { Banking and } \\
\text { Finance (BIBF) }\end{array}$ & & $\begin{array}{l}\text { fields, and } \\
\text { create and } \\
\text { manage their } \\
\text { teams }\end{array}$ & & & \\
\hline $\begin{array}{l}\text { Ahmed Al } \\
\text { Rawi }\end{array}$ & $\begin{array}{l}\text { Completed } 4 \text { years } \\
\text { of studying } \\
\text { Computer } \\
\text { Engineering at the } \\
\text { University of } \\
\text { Bahrain }\end{array}$ & & & & & \\
\hline $\begin{array}{l}\text { Hamad } \\
\text { Fuad }\end{array}$ & $\begin{array}{l}\text { Completed } 5 \text { years } \\
\text { of studying } \\
\text { Computer Science } \\
\text { at the University of } \\
\text { Bahrain }\end{array}$ & Nural & $\begin{array}{l}\text { Nural is a } \\
\text { team } \\
\text { management } \\
\text { platform } \\
\text { designed for } \\
\text { inexperienced } \\
\text { team members } \\
\text { or new that } \\
\text { allows users to } \\
\text { project } \\
\text { management } \\
\text { tools manage } \\
\text { their tasks, } \\
\text { create notes } \\
\text { and software. } \\
\text { organize their } \\
\text { team } \\
\text { communicatio } \\
\mathrm{n}\end{array}$ & $\begin{array}{l}\text { Project } \\
\text { management } \\
\text { and due date } \\
\text { automation }\end{array}$ & $\begin{array}{l}\text { March } \\
2018\end{array}$ & Seed \\
\hline $\begin{array}{l}\text { Hala } \\
\text { Sulaiman, }\end{array}$ & $\begin{array}{l}\text { Currently studying } \\
\text { Master of Business } \\
\text { Administration \& } \\
\text { Management/ } \\
\text { University of } \\
\text { Strathclyde } \\
\text { BA Mass } \\
\text { Communications/ } \\
\text { University of } \\
\text { Bahrain }\end{array}$ & \multirow[t]{2}{*}{ Al Rawi } & \multirow[t]{2}{*}{$\begin{array}{l}\text { Al-Rawi is an } \\
\text { application } \\
\text { that provides } \\
\text { users with a } \\
\text { variety of } \\
\text { audio books } \\
\text { and allows } \\
\text { them to } \\
\text { interact with } \\
\text { authors and } \\
\text { readers. }\end{array}$} & \multirow[t]{2}{*}{ Audio books } & \multirow[t]{2}{*}{$\begin{array}{l}\text { Commerci } \\
\text { al } \\
\text { Registratio } \\
\mathrm{n} \text { was on } \\
\text { 6th } \\
\text { December } \\
2016 . \\
\text { Official } \\
\text { Launch of } \\
\text { App was } \\
\text { in } \\
\text { November } \\
2017\end{array}$} & \multirow[t]{2}{*}{ Seed } \\
\hline $\begin{array}{l}\text { Mohammed } \\
\text { Ebrahim }\end{array}$ & $\begin{array}{l}\text { Masters in Business } \\
\text { Administration } \\
\text { with a } \\
\text { specialization in } \\
\text { strategy } \\
\text { /University of } \\
\text { Illinois Urbana- } \\
\text { Champaign. } \\
\text { BA in Information } \\
\text { Technology }\end{array}$ & & & & & \\
\hline
\end{tabular}




\begin{tabular}{|l|l|l|l|l|l|l|}
\hline $\begin{array}{l}\text { Name of } \\
\text { Founders }\end{array}$ & $\begin{array}{l}\text { Academic } \\
\text { Qualification }\end{array}$ & $\begin{array}{l}\text { Name } \\
\text { of Start- } \\
\text { up }\end{array}$ & $\begin{array}{l}\text { Description } \\
\text { of Start-up }\end{array}$ & $\begin{array}{l}\text { Domain/ } \\
\text { Services }\end{array}$ & $\begin{array}{l}\text { Date } \\
\text { Founded }\end{array}$ & Stage \\
\hline $\begin{array}{l}\text { Ameera Al } \\
\text { Qubaiti }\end{array}$ & $\begin{array}{l}\text { Executive } \\
\text { Professional } \\
\text { Masters Degree in } \\
\text { Islamic Finance/ } \\
\text { The General } \\
\text { Council of Islamic } \\
\text { Banks and Financial } \\
\text { Institutions } \\
\text { BA in Finance/ the } \\
\text { University College } \\
\text { of Bahrain }\end{array}$ & & & & & \\
\hline
\end{tabular}

The representatives from some of the support organizations including Participant SO11, Participant SO9, and Participant SO8 believe that the academic degree and educational background of technopreneurs can have an impact on the success of their start-ups, but they stated that the academic degree is not among their organizations' criteria for accepting to support a start-up or project. They were uncertain if there is a relationship between any specific educational background and success in this field. Although they agreed that there are some necessary skills, which must be possessed by an entrepreneur in order to succeed, most of the interviewees (10 out of 12) did not think that any specific educational degree can influence or increase the chances of success in this field. Participant SO4, for instance, indicated that they have technopreneurs who come from different educational backgrounds from all over the world.

Participant SO11, believes that the academic degree and educational background can have an impact on success, but it is not necessarily needed to build a business. She said that having a degree can enhance the required skills to become a technopreneurs, and stated that her organization works closely with universities in Bahrain.

Participant SO7 thought that the academic qualification and specialization do not determine how successful an entrepreneur can be in the market. He also thinks that "entrepreneurs need to expand their knowledge of technology because most of the dealings now and in the future are through technology". He indicated that Injazee is guiding novice technopreneurs in Bahrain to take workshops and advice from specialists in order to learn the steps of preparing a business plan.

Participant SO1 argued that the degree or academic qualification would be supportive to entrepreneurs as it provides them with the necessary knowledge to run a business. She added, "Nowadays, in order to get an academic qualification in business studies, it is a must to pass an entrepreneurship course. This allows students to have comprehensive knowledge about how to establish and manage new businesses. This also encourages students to think in an innovative way, which results in establishing new, unique, and successful businesses, and motivates them to start working on their own business and becoming entrepreneurs." Participant SO1 also believes that to become an entrepreneur, one 
does not necessarily have to have a specific degree in the field of the start-up that s/he plans to develop. She stated, "We provided support to a student who had a degree in Media and had an innovative idea but he did not have any background in programming. We involved another person who is specialized in programming in order to implement his project. The specialization is an auxiliary factor but must never be a hindrance".

\section{Support Organizations' Outlooks on the Skills Required for Technopreneurial Success}

The findings revealed that there are specific entrepreneurial skills that are considered to have a significant influence on the success of an entrepreneur or a start-up. These skills could all be in one person or could be distributed among the team members in a start-up to complement each other. For example, Participant SO5, indicated, "it is the skill set that defines success in this field". Similarly, Participant SO6, seemed to agree with Participant SO5 as he also stated, "academic qualification is not as important as a specialization, but it can be helpful. Even if the entrepreneur doesn't have the relevant knowledge, as long as they have a team or employees that do, then that is what we look at".

Correspondingly, Participant SO9 believes that there are skills that can have an important influence on entrepreneurial success, such as communication and presentation skills, which he thinks that most emerging young technopreneurs lack. He argued that skills, especially interpersonal skills, are a market practice and cannot be taught and gained through universities. Participant SO6 confirmed Participant SO9's observation as he stated, "The skills that are most lacking among technopreneurs in Bahrain are surprisingly presentation skills and organizational skills. If you cannot present or convince an audience of your project because of your lack of preparation and direction, you are doomed to fail". Participant SO3 also made the following statement, which indicates his agreement with Participants SO9 and SO6 observations: "One of the most important criteria that must be available in the student is the ability to convince the others of his/her new idea, and to have self-confidence. If the student does not have self-belief in his/her project, s/ he cannot convince others". In addition to presentation skills, Participant SO4 believes that entrepreneurs in Bahrain miss soft skills and financial modeling skills. Participant SO5 thinks that some entrepreneurs lack willingness to take risk, while Participant $\mathrm{SO} 2$ believes that they lack practical experience and financial management skills.

To further investigate the most significant skills that the technopreneurs should be equipped with in order to succeed, a short questionnaire was conducted as part of this research. Each interviewee was asked to assign a score for each skill set based on its importance ( 5 for the most important and 1 for the least important). The results, which were derived from averaging the interviewees' responses for each skill set, showed that most of the interviewees emphasized the importance of creative thinking and innovation, teamworking, strategic thinking, marketing, and communication skills respectively (figure 2) as these skills appear to be crucial for technopreneurs to succeed in convincing the investors of their ideas within few seconds. Based on the responses, creative thinking and innovation skills were the most important, while graphic design skills were the least important. 


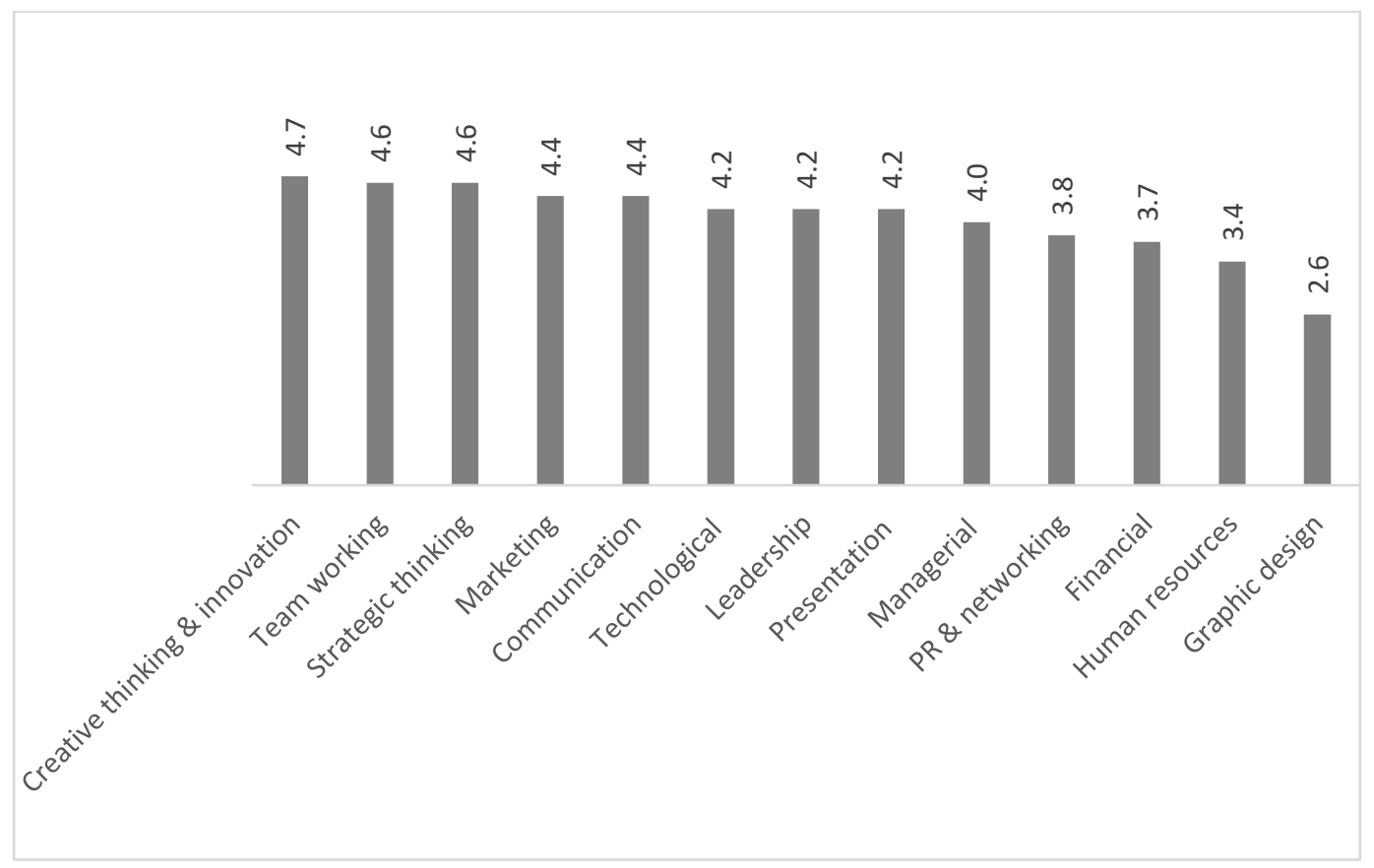

Figure 2: The rankings of the skills that are most important to have as a technopreneur according to the experts interviewed in this study (5 for most important and 1 for least important)

Participant SO11 believes that "success in this field is all about the experience of creating businesses and the learned lessons that entrepreneurs got throughout the cycle of setting up a business". She also believes that being a successful entrepreneur is a "spirit, passion and perseverance".

\section{Technopreneurs' Outlooks on the Relationship between the Educational Background and Entrepreneurial Success}

On the other hand, the technopreneurs who were interviewed as part of this study including Zaman AH Zaman, Hamad Fuad, and Ahmed Al Rawi shared the same point of view as they believe that the educational background is not the core factor of success in entrepreneurship. For instance, Al Rawi, the CEO of Malaeb app, graduated from the Computer Science Department at the University of Bahrain. He is specialized in application development. He indicated that in order to launch the application he and his partner, Yasser Abdel Aziz who has a Bachelor degree in Accounting and Finance, have developed their skills by reading books, learning from mentors, theoretical learning, and applying practical experience. Al Rawi stated, "my educational background did not contribute significantly to the success of the application in terms of the basic work nature but helped in the other tasks of the management of the company, adding that the curriculum must be practical or at least combine the theoretical and practical, and the best way to teach entrepreneurship is through practical experience". The same participant also believes that the main attributes which need to be instilled by university instructors into their students, and which led to his success as a technopreneur 
include hard work and the ability to adapt, develop and change in the face of any challenges or problems.

Abdulla Alaradi, founder of Akalati, has a Bachelor degree in Petroleum Engineering from Sultan Qaboos University. He worked in an international oil company and has eight years of experience in the field of petroleum. He said that the most important skills that he possessed, and which helped him in successfully launching a tech-start-up are "insistence and love of learning ". He stressed that these skills are very general and are not related to any specific field, whether technological or any other field. Nevertheless, regarding the skills that he developed in order to be able to launch his app, he mentioned that he started learning Information Technology and different fields of technology, which he did not learn as part of his university education. He stated, "There was a goal that I had to reach, so I learned from YouTube and Google and hired specialists from here and there, for a long time, and I had a strong belief that it is necessary to learn so that I can do what I want". He added, "I had the opportunity to attend a specialized marketing training course designed for start-ups and business owners. This session filled the gap between my skills and knowledge and enabled me to have many tools and ideas to penetrate the market with a stronger strategy and greater speed. "

Just like the founders of Malaeb App, Alaradi also said that his studies and educational background did not have a direct impact on the success of the application. He is originally an engineer and it is a very different field. The courses he took while he was in the University did not have a role in qualifying him as a business leader or technopreneur. Yet, he believes that there are certain skills and approaches that can be focused upon by educational institutions to effectively prepare potential technopreneurs. These include marketing skills. He also suggested that the educational system in Bahrain must establish students since childhood. Schools must focus on creative thinking skills so that the students reach the university having high creative abilities reflected on their personalities.

The founder of Skiplino, Zaman AH. Zaman, studied Management Information System at the American University of Sharjah for two years before transferring to the American University in Dubai where he studied Business Management Entrepreneurship Innovation. He established his first company six months after graduation. Zaman established a number of companies since 2007. Currently, he is also CEO of Level Z, which is a Start-up Studio with a vision to develop innovative start-ups and products that solve real world problems. Zaman is multi-skilled and is knowledgeable about various disciplines including Information Technology, Managed Services, Process Quality Management, Business Process Management, Cloud Computing, OOH Media, Entertainment Technology, Software Development, Ambient Advertisement, Digital Signage, and Outdoor/Indoor Advertisement. He described himself as a good marketer and CS (computer science) person. In order to develop Skiplino App, he did not take any workshops or courses to develop any skills. Instead, he had to hire employees who have the skills he is missing. Zaman indicated that he studied 
two subjects as part of his postgraduate studies, which were directly related to entrepreneurship: Production Operation and Supply Chain Management. Based on his experience, he encourages universities to offer some courses that can qualify the students and equip them with the skills they need to be successful entrepreneurs. He particularly suggested software development courses to be taught to all university students.

Hala Sulaiman, the co-founder of Al Rawi, indicated that from an academic perspective, the skills that she and her partners have complement each other and support the business along with their experiences. However, she believes that the academic qualifications only are not enough to make a tech-start-up succeed, stating,

"In my opinion, there are specific skills and traits that universities must focus on and that need to be in an entrepreneur or the team running the start-up in order to make a business succeed. Entrepreneurs need to have strong traits such as risktaking, teamwork, being customer-oriented, having the ability to network, having the discipline to run a business, and having the resilience to be able to cope with success and failure".

Hamad Fuad, the founder of Nural Technologies W.L.L., is an app developer and technopreneur. He decided to drop out from the university after five years of studying Computer Science. He decided to focus his attention on entrepreneurship and establish his own venture. One of the main reasons that led him to drop out from the university was that he found himself equipped with all the skills he needed to establish his start-up, and he felt that the university certificate is not the way to help him achieve his goal and root his own entity in the labour market. He believes that "the way of teaching at the university" was incompatible with the market needs. He also stated that the requirements and projects at the university drained his energy without gaining as many benefits as he expected to gain. He could not balance between his interest in entrepreneurship and his studies, so he decided to enter the labour market at an early age. In order to compensate for the cognitive and theoretical dimensions that he might have missed learning due to dropping out from the university, he said that he always sought to develop his skills through self-learning by watching videos, reading the latest articles and documentations, as well as learning new skills from experienced developers. Since his first semester in the university, he started learning a simple programming language. He always aspired to create his own application. His first experience of creating an application was in 2014 and it was rejected by Apple nine times due to not following human interface guidelines. Because he managed to succeed in establishing a tech start-up without completing his college education, he believes that there is no relationship between university education and success in entrepreneurship. He did not take any courses or workshops at university which taught him the necessary skills to become a technopreneur. However, he was learning by "experience and through trial and error".

Even though Hamad Fuad believes that the university certificate does not help one get a job, and although he managed to succeed without having a degree, 
Participant SO5 seems to disagree with his point of view. She thinks that "it is incorrect to say only college dropouts succeed as tech entrepreneurs. Yes, Microsoft and Facebook founders were college dropouts and showcase their intelligence and skill set, however there are many successful entrepreneurs who have college degrees and have shown the discipline of being able to finish school and start their business". In general, she believes that it is the skill set that defines one's success in this field.

Participants' Insights on the Courses and Academic Content that Universities Should Offer to Equip Potential Technopreneurs with the Necessary Skills

Participant SO5 suggested some elective courses or workshops to be taught at universities in Bahrain, such as courses that teach information technology, programming and coding to all the university students, regardless of their majors and disciplines.

In addition to the courses suggested by Participant SO5, Participant SO11 suggested that support organizations work closely with the universities to offer external short courses or workshops in cloud computing, cyber security, app development, business management, VATs training and legal training. She emphasized the necessity of the coordination between the education system and the start-up ecosystem in the country, stating that universities should review and update their curricula to meet the market needs and fit the local and regional trends.

Participant SO8 advised and directed nascent technopreneurs to start by applying for support from Tamkeen. He stressed that the academic certificate has no relevance to the success of a person in the field of work. He stated, "the way we view education needs to change. I think what is being taught at universities needs to be changed". He proposed some specific courses, skills or topics to be taught at universities in Bahrain in order to qualify technopreneurs to increase their chances of success such as: elements of design thinking, scientific methods and software programs. He also listed the following workshops that Bahrain FinTech Bay offers to technopreneurs:

- Digital Marketing

- State of AI

- Coding

- Design for non-designers

- Tech for non tech

- Idea generation

- Tools for start-ups

- State of data science

- Tech opportunities and challenges

- Prototyping your first mobile App

- Quality risk workshop

- Participant SO6 suggested additional courses and topics including the following:

- Pitch training

- How to secure funds 
- How to market your business

- How to formulate a business plan

- Networking as a topic and as an event

- How to start a business

- Market trends

- Money management

Participant SO11 recommended that universities review and update their curricula to meet the market needs and fit the local and regional trends. She added that universities should offer some programs, like fintech, for those who cannot study abroad.

Participant SO4 encouraged universities to offer students from all specializations a full entrepreneurship course that walks the student through the entire process of establishing a start-up or entrepreneurial venture. To give a good example, she referred to INJAZ Bahrain program, which is a full year program that aims to enrich students with essential entrepreneurship, networking and leadership skills in order to inspire and prepare them to succeed in a global economy. The program is annually offered to school and university students and involves a competition through which students demonstrate their proposed start-up projects and are judged for their innovation and the application of new ideas in all aspects of running the venture. The program gives the students the opportunity to mark their skills and abilities as internationally recognized qualified entrepreneurs by taking an online assessment that entitles them to getting an Entrepreneurial Skills Pass (ESP). This pass is an international qualification that certifies students to start a business. In addition to the aforementioned program by INJAZ Bahrain, the Business Incubator Centre at the University of Bahrain has recently launched The Innovation and Entrepreneurship Summer Program that involved talks and workshops by prominent entrepreneurs, professionals, and stakeholders about topics that included team formation and ideation, data science, artificial intelligence, idea validation, branding, prototyping and solution validation, customer development and problem validation, user-testing, customer engagement, business model and marketing strategy, and intellectual property for start-ups and entrepreneurs.

The findings in this paper have revealed that helping to underpin the education and entrepreneurial endeavors of technopreneurs is an important component of a well-developed ecosystem in Bahrain that is dedicated to supporting tech startups. These include a number of several support organizations, which offer a wide range of services, workshops, mentors, financial support and other forms of support to advocate for the needs and interests of nascent technopreneurs to the authorities, and promote their start-ups globally. These support organizations, however, need to coordinate closely with educational institutions in Bahrain to help them integrate technopreneurial skills into their educational programs and practices. This will help prepare and equip potential technopreneurs with the necessary skills and topics that the participants referred to and stressed on in this study. The development of the right technopreneurial skills among students in 
schools as well as in higher education institutions is critical to create and sustain a culture of technopreneurship in Bahrain.

\section{Conclusion}

This paper explored the global trends and effective practices in entrepreneurship education and examined the most important skill sets and topics that technopreneurs and support organizations' representatives recommend to be taught to students in schools and universities in Bahrain. The data and responses analyzed in this study indicate that there are a number of skills that may contribute to the success of technopreneurs and that educational institutions must focus on them. These skills were ranked, in terms of importance, by the participants in the following order: creative thinking and innovation skills, teamworking skills, strategic thinking skills, marketing skills, communication skills, technological skills, leadership skills, presentation skills, managerial skills, PR and networking skills, financial skill, human resource skills, and graphic design skills, respectively. The findings also suggest that the following topics must be offered as part of programs, courses, or workshops in educational institutions in order to bridge the skills gap and foster digital innovation and technopreneurship in Bahrain: digital marketing, artificial intelligence, coding, design, idea generation, data science, mobile app prototyping, networking, fintech, pitch training, securing funds, money management, market trends, how to market your business, how to formulate a business plan, and how to start a business.

The results reveal that more needs to be done in Bahrain in the areas of curriculum development based on international quality standards for technopreneurship education and cross-border universities and support organizations collaborations. It is vital to focus on the cultivation of qualified educators for technopreneurship education. It is also essential for educational institutions to exchange good practices and engage in a process of benchmarking among international educational institutions. Schools must place more emphasis on teaching entrepreneurship to young students. Educational institutions, in general, must focus on increasing educators' awareness and realization of the most important skills that they must hone in their students to prepare them to become successful technopreneurs. These institutions must work on equipping educators with the knowledge to implement effective practices and pedagogies to encourage technology innovation, and successfully apply technopreneurship education.

More research needs to be carried out to understand and guide the development of technopreneurship education in Bahrain. However, the findings of this paper may have implications for academics in Bahrain to promote successful technopreneurs. It may influence the considerations taken during the design of course curricula in schools and universities in Bahrain. The recommendations and opinions of the participants in this study may hopefully contribute to designing effective course contents and pedagogical approaches for teaching future technopreneurs, and in building an entrepreneurial culture in Bahrain. 


\section{Acknowledgements}

We would like to thank all the technopreneurs and support organizations representatives who have contributed greatly to our understanding of the most effective courses and workshops that educational institutions can offer, and the most important skills that universities must equip potential technopreneurs with, in order to create a generation of Bahraini pioneers who are creative, innovative, and have the appropriate attitudes, knowledge, and skills to turn their ideas into successful tech start-ups. We hope that all the information they gave us, and their opinions will reflect positively on current initiatives, strategic plans, and approaches to the integration of technopreneurship education in the educational system in Bahrain.

\section{References}

Aboukhsaiwan, O. (2017). From adversity to opportunity: Bahrain's entrepreneurship as economic resilience. Wamda. https://www.wamda.com/2017/01/bahrainentrepreneurship-economic-resilience $\backslash$

Acs, Z., Szerb, L., Lafuente, E., \& Lloyd, A. (2018). Global Entrepreneurship and Development Index 2018. Springer International Publishing. Springer Briefs in Economics. Springer. https://doi.org/10.1007/978-3-030-03279-1

Bahrain Chamber of Commerce and Industry \& Oxford Business Group. (2020). Local to Global: The Journey of Bahraini Start-Ups. https:/ / oxfordbusinessgroup.com/localglobal-journey-bahraini-start-ups

Boldureanu, G., Ionescu, A. M. Bercu, A. M., Bedrule-Grigoruță, M. V., Boldureanu, D. (2020). Entrepreneurship Education through Successful Entrepreneurial Models in Higher Education Institutions. Sustainability, 12(3), 1267. https://doi.org/10.3390/su12031267

Capiene; A., \& Ragauskaite; A. (2017). Entrepreneurship Education at University: Innovative Models and Current https:// doi.org/10.22616/RRD.23.2017.080

Center for International Private Enterprise (CIPE). (2021). Bahrain Entrepreneurship and Business Sector Reform Initiatives. https://www.cipe.org/projects/bahrain/

Dutta, S., Lanvin. B., \& Wunsch-Vincent, S. (2018). The Global Innovation Index 2018: Energizing the World with Innovation. Ithaca, Fontainebleau, and Geneva. Cornell University, INSEAD, \& WIPO. https://www.wipo.int/edocs/pubdocs/en/wipo_pub_gii_2018.pdf

Entrepreneurship 2020 Unit. (2014, November 11). Entrepreneurship Education - A guide for Educators. Brussels: European Commission: Director- General for Enterprise and Industry. http://ec.europa.eu/DocsRoom/documents/7465

Ernst \& Young. (2018). Worldwide Electronic Invoicing Survey. EYGM Limited. https://www.actuel-expert-comptable.fr/sites/default/files/ey-worldwideelectronic-invoicing-survey-2018.pdf

Ji, Z., \& Zhao, X. (2014). Analyzing elements of the employment and entrepreneurship practice education of college students. Journal of Chemical and Pharmaceutical Research, 6(7), 803 - 807. https:/ / docplayer.net/18688083-Analyzing-elements-ofthe-employment-and-entrepreneurship-practice-education-of-collegestudents.html

Kimball, D., \& Lussier, R. (2020). Entrepreneurship Skills for New Ventures. Routledge. http://doi.org/10.4324/9780429342240 
Kingdom of Bahrain Ministry of Education \& Higher Education Council (2014, October 10). The National Higher Education Strategy 2014-2024. http://www.moedu.gov.bh/hec/page.aspx?page_key=HE_Strategies\&lang=en

Kurczewska, A., \& Mackiewicz, M. (2020). Are jacks-of-all-trades successful entrepreneurs? Revisiting Lazear's theory of entrepreneurship. Baltic Journal of Management, 15(20), 411-430. https:// doi.org/10.1108/BJM-07-2019-0274

Lagaras, C. (2017). Determinants of Entrepreneurial Attributes and Intentions among Young Professionals in the Kingdom Of Bahrain. International Journal of Engineering and Management Research, 7(5), 42-51.

Liu, X., Lin, C., Zhao, G., \& Zhao, D. (2019). Research on the Effects of Entrepreneurial Education and Entrepreneurial Self-Efficacy on College Students' Entrepreneurial Intention. Front Psychol. 10, 869. http://dx.doi.org/10.3389/fpsyg.2019.00869

Lynch, M., Kamovich, U., Longva, K. K., \& Steinert, M. (2019). Combining technology and entrepreneurial education through design thinking: Students' reflections on the learning process. Technology Forecasting and Social Change. https://doi.org/10.1016/j.techfore.2019.06.015

Nebessayeva, Z., Bekbolatova, K., Mussakulov, K., Zhanbirshiyev, S., \& Tulepov, L. (2018). Promotion of entrepreneurship development by art and design by pedagogy. Opción, 34(85-2), 729-751.

OECD. (2016), Innovating Education and Educating for Innovation: The Power of Digital Technologies and Skills. OECD Publishing, Paris. http://dx.doi.org/10.1787/9789264265097-en

Oliveira, J. M., Fernandes, C., Sbragia, R., \& Borini, F. (2019). Startups and Technology Transfer from Universities and Research Centers-An Analysis of the Impact on Launching New Products. Palgrave Macmillan, Cham. https://doi.org/10.1007/978-3-030-10865-6_2

Ratzinger, D., Amess, K., Greenman, A., \& Mosey, S. (2018). The impact of digital start-up founders' higher education on reaching equity investment milestones. The Journal of Technology Transfer, 43, 760-778. https://doi.org/10.1007/s10961-017-9627-3

Sanchez, J.C., Ward, A., Hernández, B., \& Florez, J. (2017). Entrepreneurship Education: State of the Art. Propósitos y Representaciones, 5(2), 401-473. http://dx.doi.org/10.20511/pyr2017.v5n2.190

Sorgner, A., \& Fritsch, M. (2018). Entrepreneurial career paths: occupational context and thepropensity to become self-employed, Small Business Economics, 51(1). 129-152. http://dx.doi.org/10.1007/s11187-017-9917-z

Sousa, M. (2018). Entrepreneurship Skills Development in Higher Education Courses for Teams Leaders. Administrative Sciences, 8(2), 18. http://doi.org/10.3390/admsci8020018

Staniewski, M. (2016). The contribution of business experience and knowledge to successful entrepreneurship. Journal of Business Research, 69(11), 5147-5152. http://dx.doi.org/10.1016/j.jbusres.2016.04.095

Szarek, J., \& Piecuch, J. (2018). The importance of startups for construction of innovative economies. International Entrepreneurship Review, 4(2), 69-78. https:// doi.org/10.15678/PM.2018.0402.05

Startup Genome. (2020). The Global Startup Ecosystem Report 2020 (GSER2020). https://startupgenome.com/report/gser2020

Toit, A., \& Gaotlhobogwe, M. (2018). A neglected opportunity: Entrepreneurship education in lower higher school curricula for technology in South Africa and Botswana. African journal of research in mathematics, science and technology education, 22(10), 37-47. http://dx.doi.org/10.1080/18117295.2017.1420007 
Tripathi, N., Seppänen, P., Boominathan, G., Oivo, M., \& Liukkunen, K. (2019). Insights into startup ecosystems through exploration of multi-vocal literature. Information and Software Technology, 105, 56-77. https://doi.org/10.1016/j.infsof.2018.08.005

Van Burg, E., Cornelissen, J., Stam, W., \& Jack, S. (2020). Advancing Qualitative Entrepreneurship Research: Leveraging Methodological Plurality for Achieving Scholarly Impact. Entrepreneurship Theory and Practice, 1-18. https://doi.org/10.1177/1042258720943051

World Economic Forum. (2016), Unleashing Greatness. Nine Plays to Spark Innovation in Education.

www3.weforum.org/docs/WEF_WP_GAC_Education_Unleashing_Greatness.p $\mathrm{df}$ 